Original research article

\title{
Health-related quality of life measures for a cost- effectiveness analysis of ischemic stroke therapies
}

\author{
Irena Drugdová ${ }^{1}$, Vladimír Rogalewicz ${ }^{1}$, Martin Šrámek ${ }^{2}$, Veronika Kopalová ${ }^{3}$, Ondřej Krahula ${ }^{4}$, \\ Beáta Gavurová ${ }^{5}$, Miroslav Barták ${ }^{5}$ * \\ ${ }^{1}$ Czech Technical University in Prague, CzechHTA, Faculty of Biomedical Engineering, Department of Biomedical Technology, Kladno, Czech Republic \\ ${ }^{2}$ Military University Hospital, Comprehensive Stroke Center, Prague, Czech Republic, and Charles University and Motol University Hospital, Second \\ Faculty of Medicine, Department of Neurology, Prague, Czech Republic \\ ${ }^{3}$ Military University Hospital, Controlling Department, Prague, Czech Republic \\ ${ }^{4}$ Military University Hospital, Department of Radiology, Prague, Czech Republic \\ ${ }^{5}$ Charles University and General University Hospital in Prague, First Faculty of Medicine, Department of Addictology, Prague 2, Czech Republic
}

\begin{abstract}
Stroke treatment and prevention has witnessed a dramatic development in recent years, especially in developed countries. The objective of this study was to calculate the costs and cost effectiveness of the treatment of ischemic stroke in a Czech stroke center using semiobjective neurological measures - the modified Rankin Score (mRS), the National Institute of Health Stroke Scale (NIHSS), and the Modified Thrombolysis In Cerebral Infarction Scale (mTICI). Three possible interventions were investigated: intravenous thrombolysis, neurointerventional radiology, and both interventions applied in succession. In terms of both short-term and long-term effects, from the hospital as well as the health insurance company perspective, the most cost-effective intervention proved to be intravenous thrombolysis - for patients with both less and more severe stroke. This corresponds to the results of our literature search. The study supports the suitability of the chosen HRQoL measures for analyses of clinical effectiveness and cost-effectiveness of stroke therapies. In stroke patients, mRS, NIHSS, mTICI are more stable and have a better predictive value than QALYs based on patient-reported values.
\end{abstract}

Keywords: Acute ischemic stroke; Cost-effectiveness; Health technology assessment; HRQoL Specific tools; Thrombectomy; Thrombolysis

\section{Introduction}

As it has been the central part of health technology assessment (HTA) studies since the 1980s, cost-effectiveness analysis has attracted a lot of attention. The concept of quality-adjusted life years (QALY) prevails and is generally accepted in health economics including HTA. However, this concept has been repeatedly criticized (Beresniak et al., 2015; Pettitt et al., 2016). In particular, Beresniak et al. (2015) analyzed the problems in detail in their ECHOUTCOME project. Although some national HTA agencies replaced QALYs with life years gained (LYG) or other generic measures (EUnetHTA, 2015, p. 82), QALYs have remained the leading concept in evaluation of health-related quality of life (HRQoL). However, there are many disease-specific tools evaluating the HRQoL for the purpose of particular diagnoses enabling the comparison of cost-effectiveness of various interventions. This paper is devoted to analyzing cost-effectiveness of treatment options in patients with ischemic stroke using three specific (neurological) measures of HRQoL.

\section{Stroke}

Globally, stroke is the second leading cause of death (Feigin et al., 2016; Katan and Luft, 2018) and a cause of long-term disability. In developed countries, a decrease in stroke burden may be observed mainly due to improvements in prevention of risk factors, and due to good accessibility to acute treatment. Béjot et al. (2016) conclude that stroke remains an important health issue in Europe, and that the demographic ageing of the European population will lead to an increase in the total number of cases - despite the improvements in prevention and therapy indicated above. They estimated that the age-standardized incidence of stroke ranged from 95 to 290 out of 100,000 inhabitants per year in Europe, with one-month case-fatality rates ranging from $13 \%$ to $35 \%$. In the Czech Republic, 39,937 patients were hospitalized with stroke in 2010, and 8,020 of them died. As per 100,000 inhabitants, these figures correspond to 379.17 and 76.14, respectively (Zvolský, 2012). Sedova et al. (2017) showed that the overall incidence of hospitalized stroke was 241 out of 100,000 individuals in 2011.

Stroke treatment has witnessed a dramatic development in recent years. Alongside the application of new neuroradiologi-

\footnotetext{
* Author for correspondence: Miroslav Barták, Charles University and General University Hospital in Prague, First Faculty of Medicine, Department of Addictology, Apolinářská 4, 12800 Prague 2, Czech Republic; e-mail: miroslav.bartak@lf1.cuni.cz http://doi.org/10.32725/kont.2020.019

Submitted: 2020-01-08 • Accepted: 2020-04-27 • Prepublished online: 2020-04-30 
cal and neurological technologies, the main progress was due to the establishment of specialized comprehensive stroke centers (Hamann et al., 2016; Powers et al., 2018; Škoda et al., 2016). In the Czech Republic, such stroke centers were specified by the decision of the Ministry of Health in 2010 (Ministry of Health of the Czech Republic, 2010) and established by the Ministry in 2015 (Ministry of Health of the Czech Republic, 2015).

Stroke therapy can be divided into pharmacological and neuroradiological treatment. Intravenous thrombolysis is the standard when administered within 4.5 hours of symptom onset. Interventional treatment is an endovascular invasive procedure used in patients with occlusion of large cerebral artery up to 6 hours from stroke onset (in selected patients up to 24 hours). This treatment applies procedures such as clot removal, stenosis dilatation, stenting and intra-arterial thrombolysis (Powers et al., 2018; Škoda et al., 2016).

The most important randomized controlled trials were summarized in a handful of systematic reviews (Campbell et al., 2015; Carvalho et al., 2017; Moore et al., 2016; Phan et al., 2016; Rodrigues et al., 2016). Occlusion most frequently occurred in the arteria karotis interna, arteria cerebri anterior or arteria cerebri media, and the images were mostly acquired by means of CT angiography or CT perfusion imaging. It is apparent that mechanical thrombectomy significantly improves the results of the modified Rankin Scale (90-day mRS) as compared to the standard treatment using thrombolysis. The 90-day mortality rate is also lower in the endovascular group than in the reference group.

The objective of our study, based on the Master Thesis by Drugdová (2018), was to compare the clinical effectiveness and cost-effectiveness of endovascular treatment (EVT), intravenous thrombolysis (IVT), and both interventions performed in succession in patients diagnosed with ischemic stroke treated in the Comprehensive Stroke Center of the Military University Hospital in Prague (ÚVN) in 2016. The calculations are made from both the payer's (public health insurance companies) and the healthcare provider's (ÚVN) perspectives. The study includes a cost analysis for all interventions from the hospital's perspective and their comparison with reimbursements under DRG.

\section{Tools for measuring HRQoL in neurology}

There are several tools to evaluate clinical outcomes in neurology and, of course, they are convenient for measuring HRQoL in patients after stroke. In this paper, the National Institute of Health Stroke Scale (NIHSS), the modified Rankin Score (mRS) and the Modified Thrombolysis In Cerebral Infarction Scale (mTICI) are used to quantify the clinical outcomes. Their advantage is a standardized assessment that makes it possible to monitor patients' clinical state over time and to compare patients and patient groups against each other (Muir et al., 1996; Wilson et al., 2002). NIHSS is a scale with 15 components quantifying the current neurological deficit on a scale from 0 (best) to 42 (worst). It assesses the level of consciousness, speech, motor skills, sensitivity, visual field, etc. The NIHSS score corresponds to the ischemic stroke volume and the level of recanalization. The $\mathrm{mRS}$ classification serves to evaluate the consequences of acute ischemic stroke. It assesses a patient's limitations in everyday life due to the neurological deficit - on a scale from 0 (without limitations) to 6 (death). The result is identified by a series of questions (Wilson et al., 2002). The mTICI modified scale can assess the reperfusion after neurointerventional treatment. It evaluates the passage of a contrast agent in DSA on a scale from 0 (without perfusion after an occlusion) to 3 (normal perfusion) (Zaidat et al., 2013).

\section{Materials and methods}

The data were obtained by means of a retrospective observational study conducted in ÚVN for patients after ischemic stroke who received complete thrombolysis, endovascular neurointerventional treatment, or both methods in succession in 2016. These three therapeutic procedures were compared in terms of clinical effectiveness and cost-effectiveness, from both the payer's (health insurance company) and the healthcare provider's (ÚVN) perspectives. The clinical outcome was assessed by means of the modified Rankin Score (mRS), the National Institute of Health Stroke Scale (NIHSS), and the Modified Thrombolysis In Cerebral Infarction Scale (mTICI). NIHSS was assessed at admission, 24 hours, and 7 days after admission. mRS was determined by a series of questions 90 days after stroke onset. mTICI was used for the assessment of reperfusion after the neurointerventional treatment. Statistical calculations were performed using the MS Excel and $\mathrm{R}$ Commander applications. The observational study was approved by the ÚVN Ethics Committee on 27 October 2017.

The costs were calculated using the macrocosting method as a share in the closest known more general costs. The reason was that $C$ zech hospitals incl. ÚVN consider numerous cost data confidential and, besides, they do not monitor many analytical data at all (Rogalewicz et al., 2015). The hospital costs per respective patients were calculated as a proportion of the total costs of the inpatient neurological ward or of the neurological intensive care unit. They comprise personal costs, costs of drugs, blood, consumed medical materials, depreciations, energy, repairs, services, laboratory services, radiological services, "hotel services" (patient meals and accommodation), laundry, etc. If the hospital stay included a surgical intervention in the operating theatre, it was included in the costs of the case - based on the number of minutes in the operating theatre, where one minute was priced according to the operating theatre's costs. The costs also include the share of the overhead costs of the Complex Cerebrovascular Center. The overhead costs of the whole hospital, however, were not identified. This item was estimated by the staff of the Economic and Controlling Departments at $20 \%$ of the direct medical costs. Thus, the resulting amount was increased by $20 \%$. The costs do not include any follow-up rehabilitation care, as its purpose is not the treatment of acute ischemic stroke itself, but to provide a solution to its particular consequences. All the costs are stated in CZK and in EUR, and the conversion was made using the 2016 average exchange rate.

The macrocosting method described above was used to establish the total direct costs per individual patient of the respective treatment group, which, in turn, served for the calculation of the basic statistical characteristics of the given group of patients. Cost data identified in this way were used for the calculation of the cost-effectiveness ratios for individual groups of patients, seen from both the healthcare provider's and the healthcare payer's perspectives. The costs of an improvement by one NIHSS were calculated as the average costs for the given treatment group per day divided by the difference of NIHSS at admission and 24 hours after admission. The cost-effectiveness per day of treatment was calculated as the average costs per day of treatment divided by the effect, i.e. the inverted value of the reached NIHSS identified 24 hours after admission. The cost-effectiveness per hospital stay was calculated as the average costs of the whole hospital stay divided by the effect, which, in this case, was the inverted mRS 90 days after the treatment. 


\section{Sample}

A total of 147 patients with acute ischemic stroke were admitted to ÚVN between 1 January and 31 December 2016, of which 33 patients were transferred elsewhere (for non-specified reasons). The 114 patients treated in the UVN Comprehensive Stroke Center were divided into three groups according to the administered therapy (intravenous thrombolysis, mechanical recanalization, and both therapies applied in succession). For each patient, the following data were recorded anonymously: admission date, age, sex, affected brain artery, mTICI, NIHSS at admission, 24 hours and 7 days after admission, 90-day mRS, complications, whether IVT was received within one hour, and the time from the symptoms onset to the start of the treatment. NIHSS of 10 was chosen for the point separating the better and the worse prognosis. NIHSS at admission can serve as a predictor of the patient's final clinical state, and NIHSS at admission exceeding 10 indicates a suspicion of a larger artery occlusion.

\section{Results}

\section{Clinical effectiveness}

The treatment of ischemic stroke in ÚVN follows the scheme displayed in Fig. 1. Fig. 2 shows the number of patients treated by intravenous thrombolysis, neurointerventional treatment or by both methods in succession in 2016. Of the 114 patients undergoing treatment in UVN, there were 68 men and 46 women. The youngest patient was 29 years old and the oldest 97 years old, while the median age was 73 years. These data correspond to the data published in the studies from European countries summarized above.

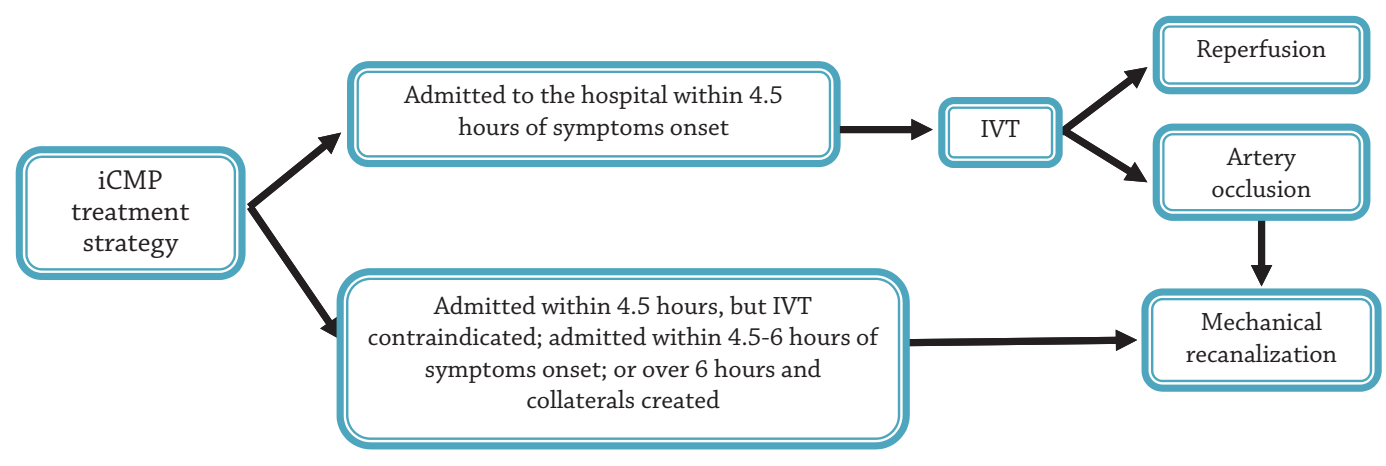

Fig. 1. Strategy of ischemic stroke treatment in the Military University Hospital (ÚVN) in Prague (Source: Šrámek, 2016)

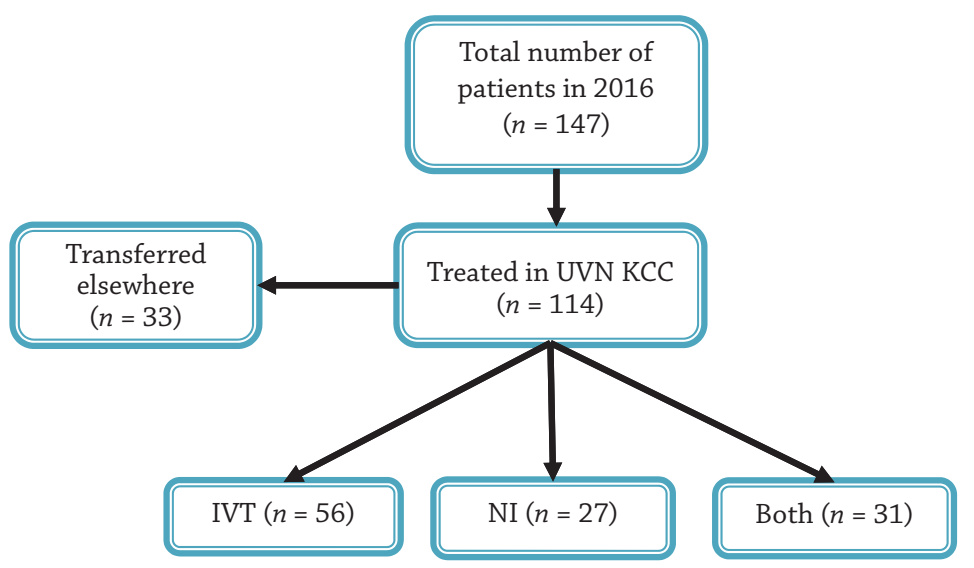

Fig. 2. Number of stroke patients admitted to ÚVN in 2016 (Source: Drugdová, 2018)

Fig. 3 displays NIHSS development 24 hours and 7 days after the intervention for patients with NIHSS at admission up to 10 . After 24 hours, the median score showed the greatest improvement for the patients treated successively by both methods (improvement by 5 NIHSS points). After 7 days, the result was identical for all treatment methods (improvement by 1 NIHSS point). Fig. 4 shows the same for patients with NIHSS at admission over 10. After 24 hours, the best results were reached in the group treated successively by both methods administered at the same time (improvement by
8.5 NIHSS points) and, after 7 days, by the group treated by IVT (improvement by 6 NIHSS points). The group treated by neurointerventional treatment only worsened by 2.5 NIHSS points (median score) after 7 days.

Fig. 5 illustrates the development of the state of patients treated by individual modalities (IVT, NIV, both interventions in succession) according to NIHSS at admission, NIHSS 7 days later, and mRS 90 days after the intervention. The straight line in the graphs on the left divides the patients who became better (below the line) from those who became worse (above the 


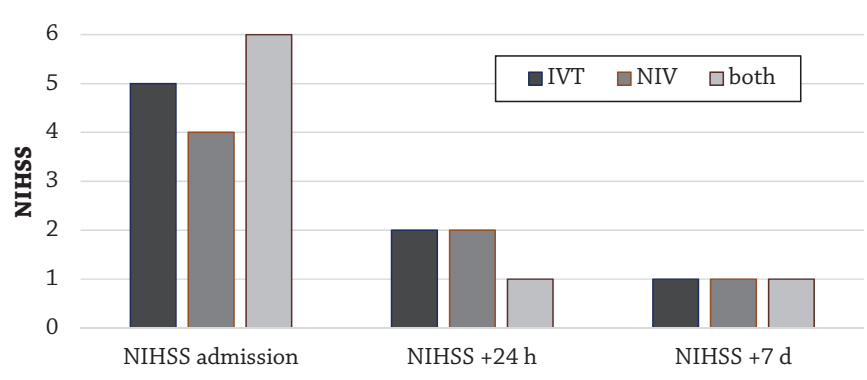

Fig. 3. NIHSS median score: comparison of interventions for patients with better prognosis (NIHSS up to 10) (Source: Drugdová, 2018)

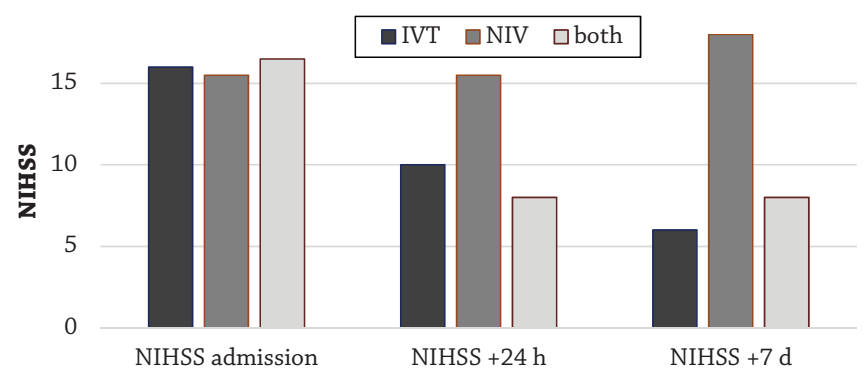

Fig. 4. NIHSS median score: comparison of interventions for patients with worse prognosis (NIHSS over 10) (Source: Drugdová, 2018) line). In the graphs on the right, the patients within the upper enclosed area did not live to 90 days, while the patients in the lower enclosed area had relatively good mRS scores.

Table 1 summarizes the clinical results (NIHSS, mRS, mTICI) for all interventions, with the patients subdivided into those with less severe stroke and better prognosis (NIHSS below 10), and those with more severe stroke and worse prognosis (NIHSS over 10). The patients with less severe stroke had excellent 90-day mRS scores in all groups, while the patients with more severe stroke did not live to 90 days or survived with bad mRS. The more severe cases treated by neurointerventional treatment did not show any improvement in the NIHSS score. The more severe cases treated by intravenous thrombolysis and by both methods successively started with a bad result, and their improvement in NIHSS was more significant than the improvement of the less severe cases - even though their total results remained worse.

\section{Costs and cost-effectiveness}

In 2016, the basic price per bed-day in the neurological department was CZK 2,317 (EUR 85.71) for a standard bed, and CZK 11,822 (EUR 437.32) for an ICU bed. Table 2 compares the costs of individual interventions from the hospital's perspective against the reimbursements from health insurance companies, i.e. costs from the payer's perspective. The costs of the treatment of less severe cases (patients with NIHSS at admission lower than 10) and the costs of the treatment of
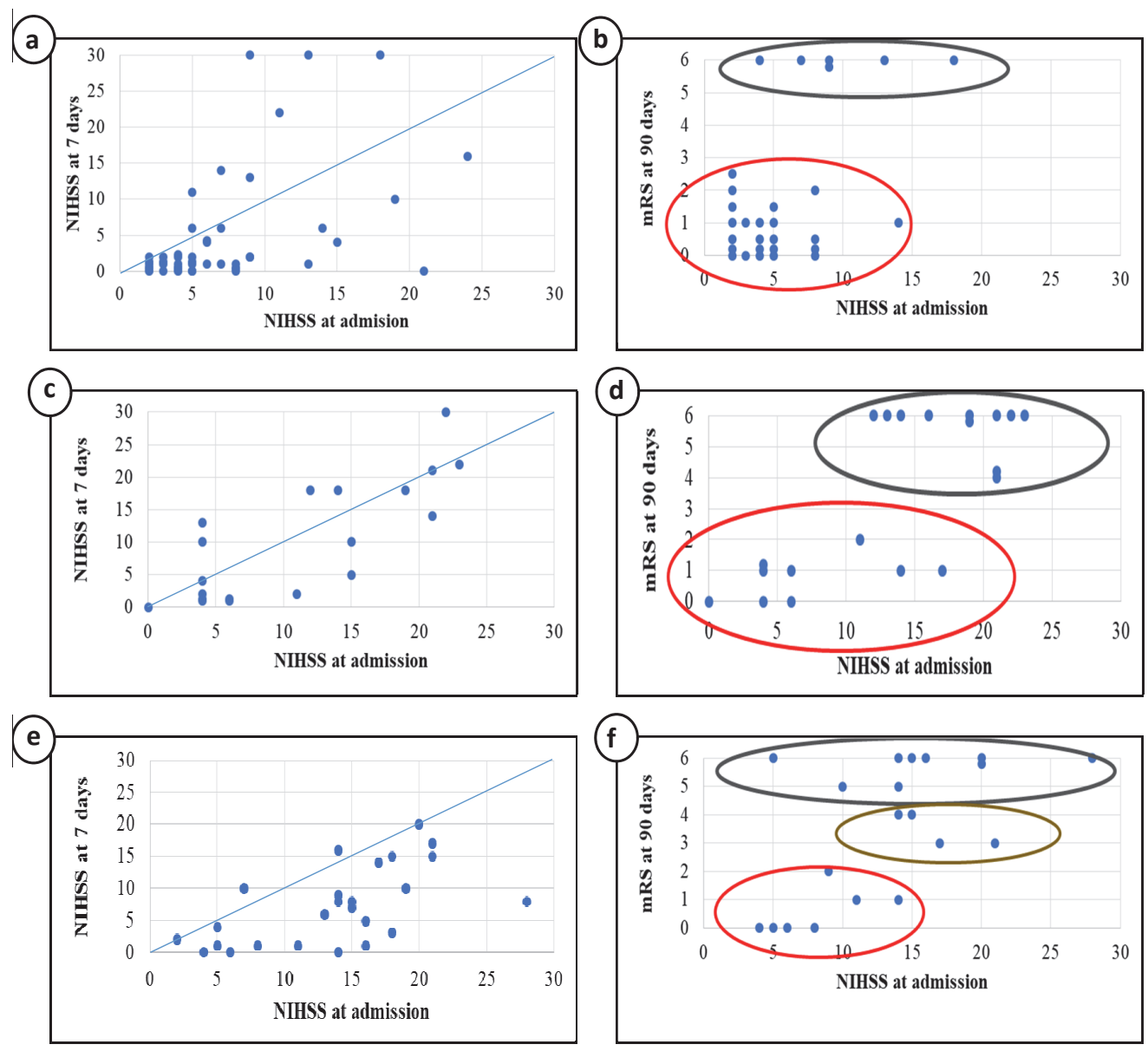

Fig. 5. Comparison of NIHSS at admission and after 7 days for patients receiving IVT (a), NIV (c) and both therapies in succession (e); comparison of NIHSS at admission and mRS after 90 days for patients receiving IVT (b), NIV (d) and both therapies in succession (f) (Source: Drugdová, 2018) 
Table 1. Summary of clinical results of patients with ischemic stroke

\begin{tabular}{|c|c|c|c|c|c|c|c|}
\hline \multirow{2}{*}{ Intervention } & \multirow{2}{*}{ Measured effect } & \multicolumn{3}{|c|}{ Less severe cases } & \multicolumn{3}{|c|}{ More severe cases } \\
\hline & & Mean & Median & STD & Mean & Median & STD \\
\hline \multirow{4}{*}{ IV thrombolysis } & NIHSS admission & 4.98 & 5 & 2.30 & 16.50 & 16 & 4.6 \\
\hline & NIHSS +24h & 2.61 & 2 & 3.1 & 11.44 & 10 & 8.62 \\
\hline & NIHSS $+7 \mathrm{D}$ or discharge & 1.95 & 1 & 3.38 & 8.43 & 6 & 8.12 \\
\hline & mRS D90 & 1.38 & 0.5 & 2.12 & 4.33 & 6 & 2.89 \\
\hline \multirow{5}{*}{ Neuro-intervention } & mTICI & 2.94 & 3 & 0.14 & 2.61 & 2.6 & 0.45 \\
\hline & NIHSS admission & 4.00 & 4 & 1.73 & 16.61 & 15.5 & 3.90 \\
\hline & NIHSS $+24 h$ & 2.75 & 2 & 2.55 & 13.14 & 15.5 & 6.60 \\
\hline & NIHSS $+7 \mathrm{D}$ or discharge & 3.67 & 1 & 4.64 & 14.22 & 18 & 7.8 \\
\hline & mRS D90 & 0.50 & 0.5 & 0.55 & 4.71 & 6 & 1.98 \\
\hline \multirow{5}{*}{ Both interventions } & mTICI & 2.83 & 3 & 0.26 & 2.57 & 3 & 0.86 \\
\hline & NIHSS admission & 6.22 & 6 & 2.54 & 17.86 & 16.5 & 5.68 \\
\hline & $\mathrm{NIHSS}+24 \mathrm{~h}$ & 6.71 & 1 & 12.32 & 9.95 & 8 & 7.36 \\
\hline & NIHSS +7D or discharge & 2.57 & 1 & 3.55 & 9.6 & 8 & 5.98 \\
\hline & mRS D90 & 1.86 & 0 & 2.61 & 4.38 & 5 & 1.89 \\
\hline
\end{tabular}

Table 2. List of costs for individual treatment modalities

\begin{tabular}{|c|c|c|c|c|c|c|c|}
\hline \multirow[t]{2}{*}{ Intervention } & \multirow[t]{2}{*}{ Cost parameter } & \multicolumn{3}{|c|}{$\begin{array}{l}\text { "Less severe cases } \\
(\text { NIHSS admission < 10)" }\end{array}$} & \multicolumn{3}{|c|}{$\begin{array}{c}\text { "More severe cases } \\
\text { (NIHSS admisson > 10)" }\end{array}$} \\
\hline & & Minimum & Mean & Maximum & Minimum & Mean & Maximum \\
\hline \multirow{7}{*}{ IV thrombolysis } & $\begin{array}{l}\text { Hospital stay } \\
\text { (days) }\end{array}$ & 2 & 10 & 38 & 4 & 11 & 23 \\
\hline & \multirow{2}{*}{$\begin{array}{l}\text { DRG reimbursement } \\
\text { (CZK/EUR) }\end{array}$} & 23961 & 48722 & 369853 & 23961 & 79825 & 405531 \\
\hline & & 886.36 & 1802.32 & 13681.54 & 886.36 & 2952.87 & 15001.33 \\
\hline & \multirow{2}{*}{$\begin{array}{l}\text { Hospital costs } \\
\text { (CZK/EUR) }\end{array}$} & 35171 & 91181 & 330038 & 40738 & 105646 & 307271 \\
\hline & & 1301.04 & 3372.95 & 12208.71 & 1506.97 & 3908.04 & 11366.52 \\
\hline & \multirow{2}{*}{$\begin{array}{l}\text { Difference } \\
\text { (CZK/EUR) }\end{array}$} & -11210 & -42459 & 39815 & -16777 & -25821 & 98260 \\
\hline & & -414.68 & -1570.64 & 1472.83 & -620.61 & -955.17 & 3634.82 \\
\hline \multirow{7}{*}{ Neuro- intervention } & $\begin{array}{l}\text { Hospital stay } \\
\text { (days) }\end{array}$ & 3 & 9 & 14 & 3 & 15 & 64 \\
\hline & \multirow{2}{*}{$\begin{array}{l}\text { DRG reimbursement } \\
\text { (CZK/EUR) }\end{array}$} & 116608 & 230420 & 485466 & 210244 & 239668 & 553441 \\
\hline & & 4313.54 & 8523.66 & 17958.27 & 7777.31 & 8865.76 & 20472.78 \\
\hline & \multirow{2}{*}{$\begin{array}{l}\text { Hospital costs } \\
\text { (CZK/EUR) }\end{array}$} & 138876 & 295096 & 584234 & 227936 & 420647 & 1086099 \\
\hline & & 5137.28 & 10916.14 & 21611.88 & 8431.77 & 15560.50 & 40176.78 \\
\hline & \multirow{2}{*}{$\begin{array}{l}\text { Difference } \\
\text { (CZK/EUR) }\end{array}$} & -22267 & -64675 & -98768 & -17692 & -180979 & -532658 \\
\hline & & -823.70 & -2392.45 & -3653.61 & -654.46 & -6694.74 & -19703.99 \\
\hline \multirow{7}{*}{ Both interventions } & $\begin{array}{l}\text { Hospital stay } \\
\text { (days) }\end{array}$ & 6 & 16 & 31 & 4 & 12 & 31 \\
\hline & \multirow{2}{*}{$\begin{array}{l}\text { DRG reimbursement } \\
\text { (CZK/EUR) }\end{array}$} & 210244 & 318785 & 969372 & 210244 & 238470 & 553441 \\
\hline & & 7777.31 & 11792.44 & 35858.34 & 7777.31 & 8821.44 & 20472.79 \\
\hline & \multirow{2}{*}{$\begin{array}{l}\text { Hospital costs } \\
\text { (CZK/EUR) }\end{array}$} & 192436 & 394528 & 916350 & 122068 & 345358 & 746665 \\
\hline & & 7118.56 & 14594.31 & 33897.46 & 4515.52 & 12775.42 & 27620.50 \\
\hline & \multirow{2}{*}{$\begin{array}{l}\text { Difference } \\
\text { (CZK/EUR) }\end{array}$} & 17808 & -75743 & 53022 & 88176 & -106888 & -193224 \\
\hline & & 658.75 & -2801.87 & 1961.38 & 3261.79 & -3953.98 & -7147.71 \\
\hline
\end{tabular}


more severe cases (patients with NIHSS at admission higher than 10) are always listed separately.

The cost-effectiveness was calculated from the healthcare provider's perspective, which better corresponds to the reality. Table 3 shows the "short-term" cost-effectiveness calculated for the first day of treatment. The clinical effect used is the difference between the 24-hour NIHSS and NIHSS at admission. The cost-effectiveness ratio was expressed as the average costs per day of treatment divided by the improvement in NIHSS during the first 24 hours. For both less severe and more severe cases, intravenous thrombolysis was the most cost-effective treatment. For less severe cases both interventions successively proved to be least cost-effective. For more severe cases, neurointerventional surgery was the least cost-effective option.

Table 3. Cost-effectiveness from the healthcare provider's perspective; average costs per day of hospital stay related to the NIHSS mean improvement within the first 24 hours

\begin{tabular}{|c|c|c|c|}
\hline & NIHSS & \multirow{2}{*}{$\begin{array}{l}\text { Mean } \\
\text { costs } \\
\text { per day } \\
(\mathrm{CZK})\end{array}$} & \multirow[t]{2}{*}{$\mathrm{C} / \mathrm{E}$} \\
\hline & $\begin{array}{l}\text { (difference at } \\
\text { admission and } \\
\text { after } 24 \mathrm{~h} \text { ) }\end{array}$ & & \\
\hline IVT $<10$ NIHSS & 2.37 & 9118 & 3847 \\
\hline IVT > 10 NIHSS & 5.06 & 9604 & 1898 \\
\hline NIV $<10$ NIHSS & 1.25 & 32788 & 26230 \\
\hline NIV > 10 NIHSS & 3.47 & 28043 & 8082 \\
\hline $\begin{array}{l}\text { Both interventions } \\
<10 \text { NIHSS }\end{array}$ & 0.49 & 24658 & 50322 \\
\hline $\begin{array}{l}\text { Both interventions } \\
>10 \text { NIHSS }\end{array}$ & 7.91 & 28780 & 3638 \\
\hline
\end{tabular}

Table 4 presents the "long-term" cost-effectiveness from the healthcare provider's perspective. Here, the clinical effect was the 3-month mRS. mRS lying between 0 (best result) and 6 (worst result) were "inverted" using the formula $\mathrm{mRSinv}=$ $1+(6-\mathrm{mRS})$. Thus, $\mathrm{mRSinv}$ ranges between 1 (worst result) and 7 (best result); the technical addition of one prevents division by zero. The intervention ranking according to cost-effectiveness was also the same from this point of view: for both less severe and more severe cases, intravenous thrombolysis was the most cost-effective therapy, for less severe cases both interventions could be considered to be the least cost-effective, while for more severe cases the neurointerventional surgery was the least cost-effective option. Therefore, the cost-effectiveness assessment did not differ in short-term and longterm results.

Hospital overhead costs represented a significant item in the healthcare provider's costs. However, the value was very roughly estimated. The staff of the Economic Department estimated the total costs incurred for hospital administration to be $20 \%$ (see Methodology). For this reason, sensitivity analysis was performed for a change in the magnitude of this item by $\pm 10 \%$. This change did not cause any alteration in the order of individual interventions.

\section{Discussion}

Compared to the selected published studies (Campbell et al., 2015; Carvalho et al., 2017; Moore et al., 2016; Phan et al., 2016; Rodrigues et al., 2016), there was higher average re-

\begin{tabular}{|c|c|c|c|c|}
\hline & $\begin{array}{c}\text { mRS after } \\
90 \text { days }\end{array}$ & mRSinv & $\begin{array}{l}\text { Total costs } \\
\quad(\mathrm{CZK})\end{array}$ & $\mathrm{C} / \mathrm{E}$ \\
\hline IVT $<10$ NIHSS & 1.38 & 5.62 & 91181 & 16224 \\
\hline IVT $>10$ NIHSS & 4.33 & 2.67 & 105646 & 39568 \\
\hline NIV $<10$ NIHSS & 0.50 & 6.50 & 295096 & 45399 \\
\hline NIV > 10 NIHSS & 4.71 & 2.29 & 420647 & 183689 \\
\hline $\begin{array}{l}\text { Both interventions } \\
<10 \text { NIHSS }\end{array}$ & 1.86 & 5.14 & 394528 & 76756 \\
\hline $\begin{array}{l}\text { Both interventions } \\
>10 \text { NIHSS }\end{array}$ & 4.38 & 2.62 & 345358 & 131816 \\
\hline
\end{tabular}

spondent age (74 years) in our study, which may have affected the higher 90-day mortality rate in the endovascular group (27.6\%) (Nam et al., 2015; Tinková and Malý, 2016). The results were also distorted by incomplete 90 -day mRS detection. We do not know the 90 -day mRS in $21 \%$ of all cases. The NIHSS median at admission appeared to be significantly better (equal to 9) in our study than in the other studies. Intravenous thrombolysis was administered to $75.4 \%$ of the patients. In our study the intervention median time was significantly lower (175 minutes), and recanalization was successful in $86 \%$. mRS of 0-2, i.e. "self-sustained patient", was reached in $36.2 \%$ of endovascularly treated patients, and in $69.6 \%$ of patients treated by intravenous thrombolysis. Thus, intravenous thrombolysis was clinically the most effective therapy. However, an intentional choice of the patients caused this (see Fig. 2). This group of patients also showed a very low 90-day mortality rate $(10.7 \%)$. It is evident that the results of the study did not depart from the results of the other studies as far as the endovascular treatment is concerned, while the results of the intravenous thrombolysis administered in ÚVN were significantly better, so that the intravenous thrombolysis overcame the endovascular intervention in the results based on mRS evaluation.

The main strategy in the treatment of acute ischemic stroke remains thrombolysis with intravenous tissue-type plasminogen activator (t-PA). With the advances in endovascular techniques and a high success rate in the administration of neurointerventional radiology, there has been a growth in endovascular interventions in recent years. However, the randomized trials published in 2013-14 did not prove the EVT benefit compared to classic IVT in the treatment of acute ischemic stroke (Broderick et al., 2013; Ciccone et al., 2013; Kidwell et al., 2013). After the design of the respective studies was reassessed, the MR CLEAN study was published in 2014 (Berkhemer et al., 2015), which changed the view of endovascular interventions. However, the issue of selecting suitable patients is still being discussed. This has been duly illustrated by various studies (Bracard et al., 2016; Campbell et al., 2018; Simpson et al., 2017; Tinková and Malý, 2016), as well as by our current study.

We expected the patients with worse NIHSS at admission (objectively more severe cases) to be more expensive on average. However, this was not confirmed in the study. It seems that the total costs of the intervention depend on a much more complex view. The results of cost-effectiveness were affected by the number of hospital stay days (less severe cases were hospitalized for a shorter time than the patients with complications), by the number of complications and, above all, 
by the material actually used. It differed, particularly, in the neurointerventional treatment, due to the variability of the used material and its amount, which differs according to the particular patient's needs and cannot be fully standardized.

From the cost-effectiveness analysis (in terms of both short-term and long-term effects) it is obvious that intravenous thrombolysis is the most effective intervention for both less severe and more severe cases from the hospitals' perspective - as well as from the health insurance perspective (assessed by the NIHSS scores at admission). For more severe cases, neurointerventional treatment is the least effective option, while for less severe cases the use of both interventions successively is the least effective. This corresponds to the results of the literature search presented above (Donaldson et al., 2016; Kumar et al., 2015; Xie et al., 2016). Neither IVT, nor neurointerventional radiology seem to be effective after six hours has passed (Powers et al., 2018; Qureshi et al., 2013; Tinková and Malý, 2016; Škoda et al., 2016); such patients were not included in our study.

The study supports the suitability of the chosen HRQoL measures for analyses of clinical effectiveness and cost-effectiveness of stroke therapies. Neurologists are used to working with their semi-objective measures (mRS, NIHSS, mTICI) and understand well the results expressed in these units. In stroke patients, they are more stable and have a better predictive value than QALYs based on patient-reported values (Chiumente et al., 2015; Ganesalingam et al., 2015). We showed that mRS and NIHSS can be well used to compare cost-effectiveness of various stroke therapies.

The results of the present study show that stroke treatment is an example of an undervalued diagnosis in the Czech Republic - the healthcare provider shows a total loss of between CZK 31,225 (EUR 1,155) and CZK 142,920 (EUR 5,287) for a hospitalization. Of course, this situation is considered unfair by the healthcare provider, who tries to negotiate higher reimbursement with the healthcare payers. However, these attempts have so far failed, since, from the systematic point of view, the result just confirms that the inpatient care reimbursement system does not reflect actual costs; it has incorporated some overvalued and/or undervalued specialties since its introduction in the late 90's. Thus, the solution does not lie in negotiating reimbursement for individual specialties, but rather in attempting to cultivate the whole inpatient care reimbursement system.

\section{Limitations of the study}

The interpretation of the study results presented above can be affected by several limitations that the authors are aware of. Most of them are due to practical aspects such as availability of data, time horizon of the study, or ethical issues.

The main limitation is the retrospective observational design of the study. Although all patients undergoing the three respective interventions in ÚVN in 2016 were included, their particular interventions were chosen intentionally (the study was not randomized).

Second, the data were collected from a single hospital. Since the ÚVN Comprehensive Stroke Center is one of the leaders in the field in the Czech Republic, and detailed national guidelines exist (Škoda et al., 2016), this probably poses no problem in terms of clinical effectiveness. Cost data and cost-effectiveness results calculated from the healthcare provider's perspective may be affected by the particular hospital processes and economic situation. Due to the uniform ways of healthcare reimbursement in the country, the results will be generally valid for all Czech Comprehensive Stroke Centers.

Third, the number of patients the study is based on is relatively low (147), which might have affected some statistical characteristics of the sample (e.g. the average age).

Finally, the follow-up check 90 days after the intervention was executed in only $79 \%$ of patients; thus, the cost-effectiveness results based on mRS taken 90 days after admission may be affected. However, Fig. 5 shows the range of NIHSS in all patients (left) and those who passed the 90-day follow-up check (right), and it does not indicate any remarkable shift.

\section{Conclusions}

The most cost-effective treatment method appears to be intravenous thrombolysis as it shows the greatest clinical benefit and, at the same time, it is also the least costly method when compared to the neurointerventional treatment and both methods applied successively. Nevertheless, the intravenous thrombolysis cannot be used in all cases, e.g. if a patient has contraindications to it, or if he/she was admitted to the hospital after more than 4.5 hours of the onset of symptoms. In patients with large cerebral artery occlusion, the endovascular treatment is used, which is costly - mainly in terms of materials.

The treatment of acute ischemic stroke belongs to the group of interventions that are undervalued in the current DRG reimbursement scheme. Adding up all costs to create a true picture of the actual expenses, the provider is at a loss ranging from CZK 31,225 (EUR 1,155.07) to CZK 142,920 (EUR 5,286.87) per hospital stay. The mean loss per inpatient bed-day is CZK 6,581 (EUR 243.44 EUR).

\section{Acknowledgements}

This research was partly supported by Charles University, Progress Programme No. Q06/LF.1.

\section{Conflicts of interests}

The authors have no conflict of interests to declare. 


\section{Míry zdravím podmíněné kvality života pro analýzu nákladové efektivity léčby ischemické cévní mozkové přihody}

\section{Souhrn}

Léčba i prevence cévních mozkových příhod (CMP) zažily v posledních letech dramatický vývoj, a to zejména v rozvinutých zemích. Cílem této studie bylo vyčíslit náklady a nákladovou efektivitu léčby CMP v českém komplexním cerebrovaskulárním centru na základě semiobjektivních neurologických nástrojů - modifikované Rankinovy škály (mRS), NIHSS (National Institute of Health Stroke Scale) a modifikované škály mTICI (Modified Thrombolysis In Cerebral Infarction Scale). Byly zkoumány tři možné intervence: intravenózní trombolýza, neurointervenční radiologie a oba výkony provedené po sobě. Jak u pacientů s lehčím, tak u pacientů s těžším průběhem CMP se z pohledu krátkodobých i střednědobých efektů jeví nákladově nejefektivnější intravenózní trombolýza, a to z perspektivy plátce i z perspektivy poskytovatele péče. To se shoduje s výsledky provedené literární rešerše. Studie prokázala vhodnost zvolených měr zdravím podmíněné kvality života pro analýzu klinické i nákladové efektivity terapií CMP. U pacientů po CMP jsou mRS, NIHSS a mTICI stabilnější a mají vyšší prediktivní hodnotu než veličina QALY, která je založena na pacientském sebehodnocení.

Klíčová slova: akutní ischemická cévní mozková příhoda; hodnocení zdravotnických technologií; HTA; nákladová efektivita; specifické nástroje HRQoL; trombektomie; trombolýza

\section{References}

1. Béjot Y, Bailly H, Durier J, Giroud M (2016). Epidemiology of stroke in Europe and trends for the 21st century. Presse Med 45(12): E391-E398. DOI: 10.1016/j.lpm.2016.10.003.

2. Beresniak A, Medina-Lara A, Auray J, De Wever A, Praet J, Tarricone R, et al. (2015). Validation of the Underlying Assumptions of the Quality-Adjusted Life-Years Outcome: Results from the ECHOUTCOME European Project. Pharmacoeconomics 33(1): 61-69. DOI: 10.1007/s40273-0140216-0.

3. Berkhemer OA, Fransen PSS, Beumer D, van den Berg LA, Lingsma HF, Yoo AJ, et al. (2015). A Randomized Trial of Intraarterial Treatment for Acute Ischemic Stroke. N Engl J Med 372(1): 11-20. DOI: 10.1056/NEJMoa1411587.

4. Bracard S, Ducrocq X, Mas JL, Soudant M, Oppenheim C, Moulin T, Guillemin F (2016). Mechanical thrombectomy after intravenous alteplase versus alteplase alone after stroke (THRACE): a randomised controlled trial. Lancet Neurol 15(11): 1138-1147. DOI: 10.1016/s1474-4422(16)30177-6.

5. Broderick JP, Palesch YY, Demchuk AM, Yeatts SD, Khatri P, Hill MD, et al. (2013). Endovascular Therapy after Intravenous t-PA versus t-PA Alone for Stroke. N Engl J Med 368(10): 893-903. DOI: 10.1056/NEJMoa1214300.

6. Campbell BCV, Donnan GA, Lees KR, Hacke W, Khatri P, Hill MD, et al. (2015). Endovascular stent thrombectomy: the new standard of care for large vessel ischaemic stroke. Lancet Neurol 14(8): 846-854. DOI: 10.1016/s1474-4422(15)00140-4.

7. Campbell BCV, Mitchell PJ, Churilov L, Yassi N, Kleinig TJ, Yan B, et al. (2018). Tenecteplase versus alteplase before endovascular thrombectomy (EXTEND-IA TNK): A multicenter, randomized, controlled study. Int J Stroke 13(3): 328-334. DOI: $10.1177 / 1747493017733935$.

8. Carvalho A, Cunha A, Rodrigues M, Figueiredo S, Paredes L, Gregório T, et al. (2017). Mechanical Thrombectomy in Acute Ischemic Stroke: Initial Single-Center Experience and Comparison with Randomized Controlled Trials. J Stroke Cerebrovasc Dis 26(3): 589-594. DOI: 10.1016/j. jstrokecerebrovasdis.2016.11.116.

9. Chiumente M, Gianino MM, Minniti D, Mattei TJ, Spass B, Kamal KM, et al. (2015). Burden of stroke in Italy: An economic model highlights savings arising from reduced disability following thrombolysis. Int J Stroke 10(6): 849-855. DOI: $10.1111 /$ ijs.12481.

10. Ciccone A, Valvassori L, Nichelatti M, Sgoifo A, Ponzio M, Sterzi R, Boccardi E (2013). Endovascular Treatment for Acute Ischemic Stroke. N Eng J Med 368(10): 904-913. DOI: 10.1056/ NEJMoa1213701.
11. Donaldson L, Fitzgerald E, Flower O, Delaney A (2016). Review article: Why is there still a debate regarding the safety and efficacy of intravenous thrombolysis in the management of presumed acute ischaemic stroke? A systematic review and meta-analysis. Emerg Med Australas 28(5): 496-510. DOI: 10.1111/1742-6723.12653.

12. Drugdová I (2018). Klinická a nákladová efektivita léčby cévní mozkové př́hody v Komplexním cerebrovaskulárním centru. (Master Thesis). Kladno: České vysoké učení technické v Praze.

13. EUnetHTA (2015). Methods for health economic evaluations A guideline based on current practices in Europe. [online] [cit. 2019-04-16]. Available from: https://eunethta.eu/wp-content/ uploads/2018/03/Methods_for_health_economic_evaluations. pdf

14. Feigin VL, Roth GA, Naghavi M, Parmar P, Krishnamurthi R, Chugh S, et al. (2016). Global burden of stroke and risk factors in 188 countries, during 1990-2013: a systematic analysis for the Global Burden of Disease Study 2013. Lancet Neurol 15(9): 913-924. DOI: 10.1016/s1474-4422(16)30073-4.

15. Ganesalingam J, Pizzo E, Morris S, Sunderland T, Ames D, Lobotesis K (2015). Cost-Utility Analysis of Mechanical Thrombectomy Using Stent Retrievers in Acute Ischemic Stroke. Stroke 46(9): 2591-2598. DOI: 10.1161/strokeaha.115.009396.

16. Hamann GF, Müller R, Alber B, Widder B (2016). Treatment in acute stroke - Stroke unit is mandatory. Neurology Psychiatry and Brain Research 22(2): 105-109. DOI: 10.1016/j. npbr.2015.12.064.

17. Katan M, Luft A (2018). Global Burden of Stroke. Semin Neurol 38(2): 208-211. DOI: 10.1055/s-0038-1649503.

18. Kidwell CS, Jahan R, Gornbein J, Alger JR, Nenov V, Ajani Z, et al. (2013). A Trial of Imaging Selection and Endovascular Treatment for Ischemic Stroke. N Engl J Med 368(10): 914-923. DOI: 10.1056/NEJMoa1212793.

19. Kumar G, Uhrig D, Fowler S, DeLaney MC, Alexandrov AV (2015). Intravenous Recombinant Tissue Plasminogen Activator Does Not Impact Mortality in Acute Ischemic Stroke at Any Time Point up to 6 Months: A Systematic Review and MetaAnalysis of Randomized Controlled Clinical Trials. CNS Drugs 29(8): 659-667. DOI: 10.1007/s40263-015-0265-8.

20. Ministry of Health of the Czech Republic (2010). Péče o pacienty s cerebrovaskulárním onemocněním v Č eské republice [Care of patients with cerebrovascular disease in the Czech Republic]. Věstník MZ ČR, No. 2: 2-13.

21. Ministry of Health of the Czech Republic (2015). Seznam center vysoce specializované péče o pacienty s iktem [List of highly specialized centers for the care of patients after acute stroke]. Věstník MZ ČR, No. 11: 52-56.

22. Moore JM, Griessenauer CJ, Gupta R, Adeeb N, Patel AS, Ogilvy CS, Thomas AJ (2016). Landmark papers in 
cerebrovascular neurosurgery 2015. Clin Neurol Neurosurg 148: 22-28. DOI: 10.1016/j.clineuro.2016.06.007.

23. Muir KW, Weir CJ, Murray GD, Povey C, Lees KR (1996).

Comparison of neurological scales and scoring systems for acute stroke prognosis. Stroke 27(10): 1817-1820. DOI: 10.1161/01. str.27.10.1817.

24. Nam J, Jing H, O’Reilly D (2015). Intra-arterial thrombolysis vs. standard treatment or intravenous thrombolysis in adults with acute ischemic stroke: a systematic review and metaanalysis. Int J Stroke 10(1): 13-22. DOI: 10.1111/j.17474949.2012.00914.x.

25. Pettitt DA, Raza S, Naughton B, Roscoe A, Ramakrishnan A, Ali A, et al. (2016). The Limitations of QALY: A Literature Review. J Stem Cell Res Ther 6(4): 1000334 DOI: 10.4172/2157-7633.1000334.

26. Phan K, Zhao DF, Phan S, Huo YR, Mobbs RJ, Rao PJ, Mortimer AM (2016). Endovascular therapy including thrombectomy for acute ischemic stroke: A systematic review and meta-analysis with trial sequential analysis. J Clin Neurosci 29: 38-45. DOI: 10.1016/j.jocn.2015.12.025.

27. Powers WJ, Rabinstein AA, Ackerson T, Adeoye OM, Bambakidis NC, Becker K, et al. (2018). 2018 Guidelines for the Early Management of Patients With Acute Ischemic Stroke: A Guideline for Healthcare Professionals From the American Heart Association/American Stroke Association. Stroke 49(3): e46-e110. DOI: 10.1161/STR.0000000000000158.

28. Qureshi AI, Miley JT, Chaudhry SA, Semaan E, Rodriguez GJ, Suri MFK, Adams HP (2013). Safety and Effectiveness of Endovascular Treatment after 6 Hours of Symptom Onset in Patients with Anterior Circulation Ischemic Stroke: A Matched Case Control Study. J Stroke Cerebrovasc Dis 22(7): 1076-1081. DOI: 10.1016/j.jstrokecerebrovasdis.2012.07.015.

29. Rodrigues FB, Neves JB, Caldeira D, Ferro JM, Ferreira JJ, Costa J (2016). Endovascular treatment versus medical care alone for ischaemic stroke: systematic review and meta-analysis. BMJ 353. DOI: 10.1136/bmj.i1754.

30. Rogalewicz V, Bartak M, Kubatova I (2015). Quality and Availability of Cost Data in Czech HTA Research. Central European Conference in Finance and Economics (CEFE2015), 548-560.

31. Sedova P, Brown RD, Zvolsky M, Kadlecova P, Bryndziar T, Kubelka T, et al. (2017). Incidence of Hospitalized Stroke in the
Czech Republic: The National Registry of Hospitalized Patients. J Stroke Cerebrovasc Dis 26(5): 979-986. DOI: 10.1016/j. jstrokecerebrovasdis.2016.11.006.

32. Simpson KN, Simpson AN, Mauldin PD, Palesch YY, Yeatts SD, Kleindorfer D, et al. (2017). Observed Cost and Variations in Short Term Cost-Effectiveness of Therapy for Ischemic Stroke in Interventional Management of Stroke (IMS) III. J Am Heart Assoc 6(5): e004513. DOI: 10.1161/jaha.116.004513.

33. Škoda O, Herzig R, Mikulík R, Neumann J, Václavík D, Bar M, et al. (2016). Klinický standard pro diagnostiku a léčbu pacientů s ischemickou cévní mozkovou př́ihodou a s tranzitorní ischemickou atakou - verze 2016 [Clinical Guideline for the Diagnostics and Treatment of Patients with Ischemic Stroke and Transitory Ischemic Attack - Version 2016]. Česká a slovenská neurologie a neurochirurgie 79(3): 351-363. DOI: 10.14735/ amcsnn2016351.

34. Šrámek M (2016). Akutní léčba ischemické CMP [Ischemic stroke acute treatment] (https://slideplayer.cz/ slide/11257648/). In (p. 57). Prague: Neurological Department, Military University Hospital.

35. Tinková M, Malý P (2016). Nová éra endovaskulární terapie v léčbě akutních iktů [The new era of endovascular therapy in the treatment of acute stroke]. Česká a slovenská neurologie a neurochirurgie 79(2): 152-159.

36. Wilson JTL, Hareendran A, Grant M, Baird T, Schulz UGR, Muir KW, Bone I (2002). Improving the assessment of outcomes in stroke - Use of a structured interview to assign grades on the modified Rankin Scale. Stroke 33(9): 2243-2246. DOI: 10.1161/01str000002743722450bd.

37. Xie X, Lambrinos A, Chan B, Dhalla IA, Krings T, Casaubon LK, et al. (2016). Mechanical thrombectomy in patients with acute ischemic stroke: a cost-utility analysis. CMAJ Open 4(2): E316325. DOI: $10.9778 / \mathrm{cmajo} .20150088$.

38. Zaidat OO, Yoo AJ, Khatri P, Tomsick TA, von Kummer R, Saver JL, et al. (2013). Recommendations on Angiographic Revascularization Grading Standards for Acute Ischemic Stroke A Consensus Statement. Stroke 44(9): 2650-2663. DOI: 10.1161/strokeaha.113.001972.

39. Zvolský M (2012). Hospitalizovaní a zemřelí na cévní nemoci mozku v ČR v letech 2003-2010 [Cerebrovascular diseases hospitalized patients and deaths in the Czech Republic in 2003-2010]. Praha: Ústav zdravotnických informací a statistiky. 